\title{
Silymarin induces inhibition of growth and apoptosis through modulation of the MAPK signaling pathway in AGS human gastric cancer cells
}

\author{
SUNG-HYUN KIM, GANG-SIK CHOO, EUN-SEON YOO, JOONG-SEOK WOO, \\ SO-HEE HAN, JAE-HAN LEE and JI-YOUN JUNG
}

Department of Companion and Laboratory Animal Science, Kongju National University, Yesan 340-702, Republic of Korea

Received January 21, 2019; Accepted July 17, 2019

DOI: $10.3892 /$ or.2019.7295

\begin{abstract}
Apoptosis is regarded as a therapeutic target because it is typically disturbed in human cancer. Silymarin from milk thistle (Silybum marianum) has been reported to exhibit anticancer properties via regulation of apoptosis as well as anti-inflammatory, antioxidant and hepatoprotective effects. In the present study, the effects of silymarin on the inhibition of proliferation and apoptosis were examined in human gastric cancer cells. The viability of AGS human gastric cancer cells was assessed by MTT assay. The migration of AGS cells was investigated by wound healing assay. Silymarin was revealed to significantly decrease viability and migration of AGS cells in a concentration-dependent manner. In addition, the number of apoptotic bodies and the rate of apoptosis were increased in a dose-dependent manner as determined by DAPI staining and Annexin V/propidium iodide double staining. The changes in the expression of silymarin-induced apoptosis proteins were investigated in human gastric cancer cells by western blotting analysis. Silymarin increased the expression of Bax, phosphorylated (p)-JNK and p-p38, and cleaved poly-ADP ribose polymerase, and decreased the levels of Bcl-2 and p-ERK1/2 in a concentration-dependent manner. The in vivo tumor growth inhibitory effect of silymarin was investigated. Silymarin (100 mg/kg) significantly decreased the AGS tumor volume and increased apoptosis, as assessed by the TUNEL assay, confirming its tumor-inhibitory effect. Immunohistochemical staining revealed elevated expression of p-JNK and p-p38 as well as reduced expression of p-ERK1/2 associated with silymarin-treatment. Silymarin was revealed to reduce tumor growth through inhibition of p-ERK and activation of p-p38 and p-JNK in human gastric cancer cells. These results
\end{abstract}

Correspondence to: Professor Ji-Youn Jung, Department of Companion and Laboratory Animal Science, Kongju National University, Yesan 340-702, Republic of Korea

E-mail: wangza@kongju.ac.kr

Key words: gastric cancer, AGS, silymarin, apoptosis, MAPK signaling, xenograft indicated that silymarin has potential for development as a cancer therapeutic due to its growth inhibitory effects and induction of apoptosis in human gastric cancer cells.

\section{Introduction}

The frequency and mortality rate of cancer are increasing in South Korea (1-3). Gastric cancer is the fourth most common type of cancer, and has the second highest mortality rate after lung cancer worldwide (4). Approximately 990,000 people are diagnosed with gastric cancer in the world every year, of which approximately 738,000 succumb to this disease. The incidence rate of gastric cancer is two to three times higher in men than in women, with the rates varying by country (5). North America and most regions in Africa exhibit the lowest incidence rates of gastric cancer, whereas East Asia, Eastern Europe, and South America have the highest rates (6). The mortality rate of gastric cancer is the highest among all types of cancer in South Korea, China, and other East Asian countries, and is rapidly increasing. Currently, surgery and chemotherapy are used to treat gastric cancer alternating various types of therapies to raise the effectiveness of treatment, however, the recurrence rates are high even after surgery and the survival rate is low, leading to poor prognosis. Therefore, new treatment methods are required to improve the prognosis of gastric cancer patients (7-9). Medications produced from various natural ingredients and resources are being increasingly used as new methods of treatment, and some studies have confirmed marked effects of some natural resources for anticancer treatment and immunoregulation (10-12).

Flavonoids are widely distributed in plants, such as fruits and vegetables, and have various structural properties. Many plants have long been consumed to regulate various internal biological activities $(13,14)$. The roles of such natural products in cancer prevention and chemotherapy have been widely studied to examine their potential as anticancer agents mediated through various effects, including antioxidation, inhibition of vascularization, induction of apoptosis and differentiation, and cell cycle arrest (15).

As a natural product acquired from the fruits and seeds of the milk thistle plant (Silybum marianum L.), silymarin is a compound that contains silibinin, isosoi slybin, silydianin, 
and silychristin, which are flavonoids. For several decades, it has been used as a functional food in liver protection and in the treatment of chronic epilepsy $(16,17)$. Recent studies have revealed that it alters the expression of proteins related to cell cycle regulation and apoptosis and thus controls the balance between cell viability and apoptosis and exhibits anti-inflammatory, vascularization inhibitory, antioxidative, and anti-metastasis effects (18-20). It has also been reported to exhibit anticancer effects in liver (21), colorectal (22), breast (23), lung (24), and prostate cancer (25).

Apoptosis is an intracellular activity also known as programmed cell death or cellular suicide, which plays central roles in maintaining homeostasis by regulating the number of cells and removing dysfunctional and unnecessary cells that cannot recover from damage (26). Apoptosis is mediated through two pathways: The extrinsic pathway mediated by death receptors, and the intrinsic pathway mediated by mitochondria. The extrinsic pathway works by activating caspase with death receptors located on the cell membrane that forms a complex with a death ligand $(27,28)$. The intrinsic pathway refers to apoptosis completed through the release of apoptosis-related inducers in mitochondria through changes in mitochondrial membrane permeability (MMP) (29). The Bcl-2 family is a major protein type involved in the intrinsic pathway that regulates MMP according to changes in its expression. Among these proteins, Bax forms the apoptosome when its expression increases as a pro-apoptotic protein and activates caspase-3 to induce apoptosis. Bcl-2 inhibits Bax as an anti-apoptotic protein, and thus inhibits the induction of apoptosis (30). In addition, poly(ADP ribose) polymerase (PARP) is a regulator of apoptosis that plays an important role in DNA repair in the nucleus (31).

The protein kinase, mitogen-activated protein kinases (MAPK), plays an important role in cell death, proliferation, and differentiation as a major signaling molecule that that delivers extracellular stimuli to the nucleus. MAPK is classified into extracellular signal-regulated protein kinase $1 / 2$ (ERK1/2), c-Jun N-terminal kinase/stress-activated protein kinase (JNK/SAPK), and p38. ERK1/2 mediates signal transmission of growth hormone and thus plays important roles in cellular proliferation, differentiation, and cell viability. JNK and p38 are activated by stimuli, such as extracellular stress, and play essential roles in inflammation and cell death (32).

The present study was performed to examine the effects of the flavonoid, silymarin, on tumor growth inhibition and induction of apoptosis in AGS human gastric cancer cells, and to determine whether the induced apoptosis was mediated by the MAPK pathway to confirm its tumor growth inhibitory effects in vivo.

\section{Materials and methods}

Reagents. The AGS human gastric cancer cells used for this study were purchased from the Korea Cell Line Bank (Seoul, Korea). RPMI-1640, used for cell culture, was purchased from Welgene (Gyeonsan, Korea), and fetal bovine serum (FBS) and streptomycin/penicillin were purchased from Gibco BRL; Thermo Fisher Scientific, Inc. Silymarin and general reagents used in this study were purchased from Sigma-Aldrich; Merck KGaA. The primary antibodies (anti- $\beta$-actin, anti-Bax,
anti-Bcl-2, anti-PARP, anti-Erk1/2, anti-phosphorylated (p)-Erk1/2, anti-JNK, anti-p-JNK, anti-p38, anti-p-p38), and secondary antibody (anti-rabbit IgG) were purchased from Cell Signaling Technology, Inc. Matrigel matrix was purchased from Corning, Inc.

Cell culture. AGS human gastric cancer cells were cultured in the incubator at $37^{\circ} \mathrm{C}$ and $5 \% \mathrm{CO}_{2}$ in RPMI-1640 culture medium supplemented with $1 \%$ streptomycin/penicillin and $5 \%$ FBS. When the cell density reached $\sim 80 \%$ in $175-\mathrm{cm}^{2}$ flask, the cells were washed with the phosphate-buffered saline (PBS; pH 7.4) and treated with trypsin-EDTA for subculture. The culture medium was replaced every $~ 2-3$ days.

Cell viability assay. An MTT assay was performed to investigate the effect of silymarin on proliferation of AGS human gastric cancer cells. AGS cells were seeded in 96-well plate at a density of $2 \times 10^{4}$ cells $/ \mathrm{ml}$ and cultured in the RPMI-1640 culture medium for $24 \mathrm{~h}$ in an incubator at $37^{\circ} \mathrm{C}$ and $5 \%$ $\mathrm{CO}_{2}$. The cells were then treated with silymarin at concentrations of $0,20,40,60,80,100$ and $120 \mu \mathrm{g} / \mathrm{ml}$. After $24 \mathrm{~h}$, MTT [3-(4,5-dimethylthiazol-2-yl)-2,5-diphenyltetrazolium bromide] solution was added to the 96 -well plates containing AGS cells in a volume of $40 \mu \mathrm{l} /$ well and cultured for $2 \mathrm{~h}$. After removing the MTT solution, $100 \mu \mathrm{l} /$ well of dimethyl sulfoxide (DMSO) was added to dissolve all formazan formed in the well, and the absorbance was measured at $595 \mathrm{~nm}$ with an ELISA-reader (Bio-Rad Laboratories Inc.). The percentage of viable cells was estimated in comparison to the untreated control cells.

Wound healing assay. AGS human gastric cancer cells were seeded in a 60-mm dish and cultured for $24 \mathrm{~h}$. A uniform wound was created by scratching cells with a sterile $1-\mathrm{ml}$ blue-pipette tip. The culture medium was replaced with that containing silymarin at concentrations of 0,40 and $80 \mu \mathrm{g} / \mathrm{ml}$, followed by culture for $24 \mathrm{~h}$. After $24 \mathrm{~h}$, the wound healing rates of cells treated with silymarin at concentrations of 40 and $80 \mu \mathrm{g} / \mathrm{ml}$ and those without silymarin were examined on images captured under a phase contrast microscope (x200) at 0 and $24 \mathrm{~h}$ after wound incision.

DAPI staining. 4',6-Diamidino-2-phenylindole (DAPI) staining was performed to examine the specific morphological changes in the nuclei with induction of apoptosis. AGS human gastric cancer cells were seeded in a 60 -dish at $1 \times 10^{5}$ cells $/ \mathrm{ml}$, stabilized for $24 \mathrm{~h}$, treated with silymarin at 0,40 and $80 \mu \mathrm{g} / \mathrm{ml}$, and cultured in an incubator for $24 \mathrm{~h}$. The cells were then washed twice with PBS and fixed with the $4 \%$ paraformaldehyde solution for $15 \mathrm{~min}$. Subsequently, they were washed again with PBS, treated with 1:10 diluted DAPI solution $(2 \mathrm{ml})$, and observed under a fluorescence microscope (Zeiss AG) at an x200 magnification in a dark room.

Flow cytometric analysis. Apoptosis was measured using an FITC-Annexin V apoptosis detection kit (BD Pharmingen). For Annexin V-propidium iodide (PI) staining, AGS human gastric cancer cells were treated with silymarin at concentrations of 0,40 and $80 \mu \mathrm{g} / \mathrm{ml}$. Cells cultured for $24 \mathrm{~h}$ were washed with PBS, suspended in trypsin-EDTA, and centrifuged 
$\left(260 \mathrm{x} \mathrm{g}, 5 \mathrm{~min}, 4^{\circ} \mathrm{C}\right.$ ) to obtain the cell pellet. They were then washed twice with cold PBS and centrifuged to obtain the cell pellet. Next, they were suspended in $1 \mathrm{X}$ binding buffer at a concentration of $1 \times 10^{6}$ cells $/ \mathrm{ml}$. Fluorescein isothiocyanate (FITC)-conjugated Annexin V and phycoerythrin (PE)-conjugated PI were then added and reacted for $15 \mathrm{~min}$ followed by flow cytometry.

Western blot analysis. Western blot analysis was performed to determine the changes in protein expression associated with silymarin treatment. AGS human gastric cancer cells cultured in $175-\mathrm{cm}^{2}$ flasks in an incubator at $37^{\circ} \mathrm{C}$ and $5 \% \mathrm{CO}_{2}$ were treated with silymarin at concentrations of 0,40 and $80 \mu \mathrm{g} / \mathrm{ml}$ and cultured for $24 \mathrm{~h}$. Trypsin-EDTA was added to the cells, which were then suspended and centrifuged $(260 \mathrm{x} \mathrm{g}, 5 \mathrm{~min}$, $4^{\circ} \mathrm{C}$ ). Cell lysis buffer (Invitrogen; Thermo Fisher Scientific, Inc.) was added to the cell pellet, and allowed to react at $4^{\circ} \mathrm{C}$ for $20 \mathrm{~min}$. The supernatant obtained by centrifugation at $15,000 \mathrm{x} \mathrm{g}$ for $5 \mathrm{~min}$ was used as the cell lysate. The concentration of the extracted protein was determined by Bradford protein assay. Proteins were separated by $12 \%$ sodium dodecyl sulfate-polyacrylamide gel electrophoresis (SDS-PAGE) and transferred onto nitrocellulose membranes (Bio-Rad Laboratories, Inc.). The membranes were blocked with 5\% skim milk for $2 \mathrm{~h}$, followed by the addition of the primary antibodies anti- $\beta$-actin $(1: 1,000$; cat. no. 4967$)$, anti-Bax (1:1,000; cat. no. 2772), anti-Bcl-2 (1:1,000; cat. no. 2876), anti-PARP (1:1,000; cat. no. 9542), anti-Erk1/2 (1:1,000; cat. no. 9102), anti-p-Erk1/2 (1:1,000; cat. no. 9101), anti-JNK (1:1,000; cat. no. 9252), anti-p-JNK (1:1,000; cat. no. 4668), anti-p38 (1:1,000; cat. no. 9212), and anti-p-p38 (1:1,000; cat. no. 4631$)$, and left overnight at $4^{\circ} \mathrm{C}$. Anti-rabbit $\operatorname{IgG}(1: 1,000$; cat. no. 7074) (all from Cell Signaling Technology, Inc.) was then added and allowed to react for $2 \mathrm{~h}$. The results were obtained using the ECL detection reagent (Pierce; Thermo Fisher Scientific, Inc.). The density of each band was measured using the ImageJ Launcher imaging program (version 1.48; provided by NCBI).

In vivo xenograft tumor model. Ten $\mathrm{BALB} / \mathrm{c}$ nude mice (Four-week-old, male, $20 \mathrm{~g}$ ) were purchased from the Nara-Biotec (Seoul, Korea). The mice were housed in isolated and ventilated cages ( $\leq 3$ mice per cage). Mice were maintained under a 12-h light/dark cycle, and housed under controlled temperature $\left(23 \pm 3^{\circ} \mathrm{C}\right)$ and humidity $(40 \pm 10 \%)$ conditions. Mice were allowed access to laboratory pelleted food and water ad libitum. Cervical dislocation was used to sacrifice the mice. AGS human gastric cancer cells were cultured in an incubator at $37^{\circ} \mathrm{C}$ and $5 \% \mathrm{CO}_{2}$ in RPMI-1640 culture medium containing 5\% FBS. When the cell density reached approximately $80-90 \%$, they were transferred into $175-\mathrm{cm}^{2}$ flasks and suspended by addition of trypsin-EDTA, followed by centrifugation $\left(260 \mathrm{x} \mathrm{g}, 5 \mathrm{~min}, 4^{\circ} \mathrm{C}\right)$. They were then washed with PBS and centrifuged again $\left(260 \mathrm{x} \mathrm{g}, 3 \mathrm{~min}, 4^{\circ} \mathrm{C}\right)$ to obtain the cell pellet, which was divided into aliquots in culture medium at a concentration of $1 \times 10^{7}$ cells $/ \mathrm{ml}$. AGS cells were injected in a volume of $200 \mu \mathrm{l}$ (1:1 Matrigel mixture) into the backs of male BALB/c nude mice. One week later, after tumors had formed, the mice were anesthetized with diethyl ether and the tumor tissue was extracted, cut into blocks $\sim 1 \mathrm{~mm}^{3}$, and then reinjected into nude mice. Diethyl ether was provided as inhalant. They were grouped according to uniform tumor size. The injected group received oral administration of $100 \mathrm{mg} / \mathrm{kg}$ of silymarin diluted in ethanol five times per week, at the same time of day in each session, for 2 weeks. The control group received oral administration of a mixture of ethanol and distilled water according to the same schedule for 2 weeks. During the administration period, the general conditions of the mice were examined, and tumor size was measured twice a week with Vernier calipers (Mitutoyo Corporation) and calculated as follows: Size $\left(\mathrm{mm}^{3}\right)=[0.5 \mathrm{x}(\text { length }+ \text { width })]^{3}$. The animal experiments were conducted in accordance with the regulations of the Institutional Animal Care and Use Committee with the approval of the Ethics Committee in the Kongju National University.

TUNEL assay. TUNEL assays were performed to identify apoptotic cells using the Dead End Colorimetric TUNEL System (Promega Corportaion). Paraffin-embedded tissue sections $5-\mu \mathrm{m}$ thick were deparaffinized with xylene, followed by rehydration using a graded series of 100, 95, 85, 70 and $50 \%$ ethanol. After washing with PBS, proteinase $\mathrm{K}$ was added to each slide and allowed to react at room temperature for $15 \mathrm{~min}$. The equilibration buffer, biotinylated nucleotide mixture, and recombinant terminal deoxynucleotidyl transferase (rTdT) were mixed, added to each slide, and allowed to react at $37^{\circ} \mathrm{C}$ for $1 \mathrm{~h}$. Then, $0.3 \%$ hydrogen peroxide $\left(\mathrm{H}_{2} \mathrm{O}_{2}\right)$ in PBS was added and allowed to react for $5 \mathrm{~min}$. Streptavidin-HRP was added to each slide, on which 3,3'-diaminobenzidine tetrahydrochloride (DAB) solution was reacted for $10 \mathrm{~min}$ and positive cells were observed under a light microscope (x200).

Immunohistochemistry. After examination of apoptotic cells by TUNEL assay, immunohistochemistry (IHC) was performed to investigate for target proteins related to apoptosis. Paraffin-embedded tissue sections 5- $\mu \mathrm{m}$ thick were deparaffinized with xylene, followed by rehydration using a graded series of 100, 90, 80 and $70 \%$ ethanol. After washing with PBS, intrinsic peroxidase was deactivated with $0.3 \% \mathrm{H}_{2} \mathrm{O}_{2}$. After washing with PBS, intrinsic biotin was deactivated with skim milk, and sections were reacted with the primary antibody. After washing, sections were reacted with the secondary antibody, and $\mathrm{H}_{2} \mathrm{O}_{2}$ was added to DAB to undergo reaction. Sections were then stained with methyl green, and the target proteins were observed under a light microscope (x200).

Histological examination. To investigate organ homogeneity by silymarin, test animals were sacrificed, and their livers and kidneys were extracted. Paraffin-embedded tissue sections $5-\mu \mathrm{m}$ thick were deparaffinized with xylene, and rehydrated with 100 and $95 \%$ ethanol. They were then stained with hematoxylin and eosin (H\&E) and observed under a light microscope (x200) after hydration and transparency processes.

Statistical analysis. The results are expressed as the means \pm standard deviation (SD). Differences between the mean values for the groups were assessed by a one-way analysis of variance (ANOVA) and Dunnett's t-tests. $\mathrm{P}<0.05$ was considered to indicate a statistically significant difference. 


\section{Results}

Effects of silymarin on the viability of AGS human gastric cancer cells. To evaluate its effects on the viability of AGS human gastric cancer cells, silymarin was applied at different concentrations and the results were examined by MTT assay. Cancer cells were divided into aliquots of $2 \times 10^{4}$ cells $/ \mathrm{ml}$ in 96-well plates, cultured for $24 \mathrm{~h}$, and treated with silymarin at $0,20,40,60,80,100$ and $120 \mu \mathrm{g} / \mathrm{ml}$ for $24 \mathrm{~h}$. The viability of AGS cells was $77.9 \%$ in the presence of $20 \mu \mathrm{g} / \mathrm{ml}$ silymarin, $71.5 \%$ at $40 \mu \mathrm{g} / \mathrm{ml}, 59.8 \%$ at $60 \mu \mathrm{g} / \mathrm{ml}, 44.5 \%$ at $80 \mu \mathrm{g} / \mathrm{ml}$, $35.3 \%$ at $100 \mu \mathrm{g} / \mathrm{ml}$ and $33.9 \%$ at $120 \mu \mathrm{g} / \mathrm{ml}$. These results indicated a significant concentration-dependent inhibitory effect on the viability of AGS cells starting at $20 \mu \mathrm{g} / \mathrm{ml}$ (Fig. 1).

Effects of silymarin on the migration of AGS human gastric cancer cells. A wound healing assay was performed to examine the effects of silymarin on the migration of the AGS human gastric cancer cells. AGS gastric cancer cell cultures with a wound of a specific size were treated with silymarin at 0,40 and $80 \mu \mathrm{g} / \mathrm{ml}$, and cultured for $24 \mathrm{~h}$. The effects of silymarin on cell migration were examined by comparing the degree of wound healing at specified intervals. Silymarin was revealed to inhibit the migration of the AGS cells in a concentration-dependent manner (Fig. 2A). The numbers of cells present at various time-points were counted. In comparison with the control group, silymarin was confirmed to inhibit migration of AGS cells in a concentration-dependent manner (59.4\% at $40 \mu \mathrm{g} / \mathrm{ml}$ and $21.7 \%$ at $80 \mu \mathrm{g} / \mathrm{ml}$ ) (Fig. 2B).

Morphological changes in AGS human gastric cancer cells induced by silymarin. The experiments outlined above confirmed the inhibitory effect of silymarin on the viability and migration of AGS human gastric cancer cells. To examine whether these effects were related to apoptosis, AGS cells were treated with silymarin at concentrations of 40 and $80 \mu \mathrm{g} / \mathrm{ml}$. DAPI staining was then performed to examine morphological changes in the nucleus and the phenomenon of chromatin condensation by fluorescence microscopy (Fig. 3A). The proportion of cells exhibiting positive DAPI staining increased, while the cell count decreased. The growth of AGS cells was inhibited in a concentration-dependent manner similar to the results of the MTT and wound healing assays. One hundred cells from five random fields at x200 magnification under a fluorescence microscope were quantified to analyze the degree of apoptosis induction. The proportion of cells exhibiting chromatin and nuclear condensation as well as morphological changes associated with apoptosis increased in the silymarin-treated group in a concentration-dependent manner (2\% at $0 \mu \mathrm{g} / \mathrm{ml}, 13 \%$ at $40 \mu \mathrm{g} / \mathrm{ml}$ and $42.2 \%$ at $80 \mu \mathrm{g} / \mathrm{ml}$ ) in comparison with the controls (Fig. 3B).

Effects of silymarin on apoptosis in AGS human gastric cancer cells. DAPI staining indicated a close relationship between silymarin and apoptosis in reduction of AGS human gastric cancer cell viability and proliferation. To examine the degree of apoptosis induction, Annexin V/PI staining was applied to AGS cells treated with silymarin at concentrations of 0,40 and $80 \mu \mathrm{g} / \mathrm{ml}$ and cultured for $24 \mathrm{~h}$, after which apoptotic cells were determined by flow cytometry (Fig. 4A). Comparison of the total ratio of early to late apoptosis cells indicated

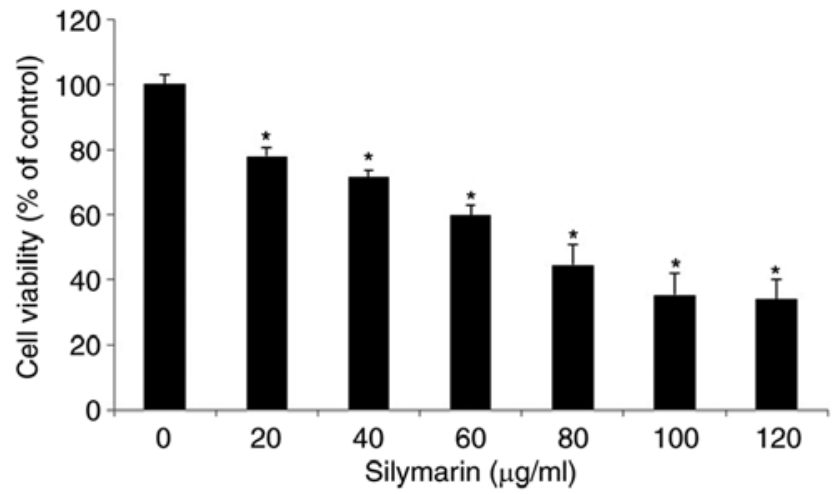

Figure 1. Effects of silymarin on the cell viability of AGS human gastric cancer cells. The results are revealed cell viability inhibitory effect of silymarin on AGS cells. Cell viability was measured by the MTT assay. The results are presented as the mean \pm SD from three independent experiments performed in triplicate. Significance was determined by Dunnett's t-test with ${ }^{*} \mathrm{P}<0.05$ considered as statistically significant compared with non-treated controls.

silymarin concentration-dependent increases of $23.36 \%$ at $0 \mu \mathrm{g} / \mathrm{ml}, 31.72 \%$ at $40 \mu \mathrm{g} / \mathrm{ml}$ and $52.13 \%$ at $80 \mu \mathrm{g} / \mathrm{ml}$ (Fig. 4B).

Effects of silymarin on apoptosis-related proteins in AGS human gastric cancer cells. Western blotting was performed to examine the changes in the expression levels of apoptosis-related proteins following treatment of AGS human gastric cancer cells with silymarin at concentrations of 0,40 and $80 \mu \mathrm{g} / \mathrm{ml}$ (Fig. 5A). The results indicated concentration-dependent increases in the expression levels of the pro-apoptotic proteins, Bax and cleaved PARP, while expression of the anti-apoptotic protein, Bcl-2, was decreased in AGS cells treated with silymarin at 40 and $80 \mu \mathrm{g} / \mathrm{ml}$ (Fig. 5B).

Effects of silymarin on the MAPK pathway in AGS human gastric cancer cells. Changes in proteins involved in the MAPK signaling pathway were examined in AGS human gastric cancer cells treated with silymarin at concentrations of 0,40 and $80 \mu \mathrm{g} / \mathrm{ml}$ for $24 \mathrm{~h}$ (Fig. 6A). The results indicated concentrationdependent decreases in the expression of p-ERK1/2 and increases in the expression of p-JNK and p-p38 (Fig. 6B).

Effects of silymarin on tumor growth in vivo in an animal model. In an in vivo experiment with reference to the in vitro findings, xenografting was performed in 4-week-old male BALB/c nude mice to examine the effects of silymarin injection on AGS human gastric cancer cell-derived tumors. The tumor size and body weight of the animals were measured twice per week. Silymarin was diluted in ethanol and orally administered five times per week at 0 or $100 \mathrm{mg} / \mathrm{kg}$ for 2 weeks. The control group received oral administration of ethanol and distilled water according to the same schedule for 2 weeks. The results indicated that the tumor size decreased in the silymarin injection group from 7 days after commencement of administration. The degree of decrease in tumor size was higher in the group administered $100 \mathrm{mg} / \mathrm{kg}$ silymarin (Fig. 7A). At 14 days, the $100 \mathrm{mg} / \mathrm{kg}$ silymarin injection group exhibited a $46.2 \%$ decrease in tumor size in comparison with the control group (Table I). The final tumor size was $1,230 \mathrm{~mm}^{3}$ in the control group and $661 \mathrm{~mm}^{3}$ in the $100 \mathrm{mg} / \mathrm{kg}$ silymarin 
A

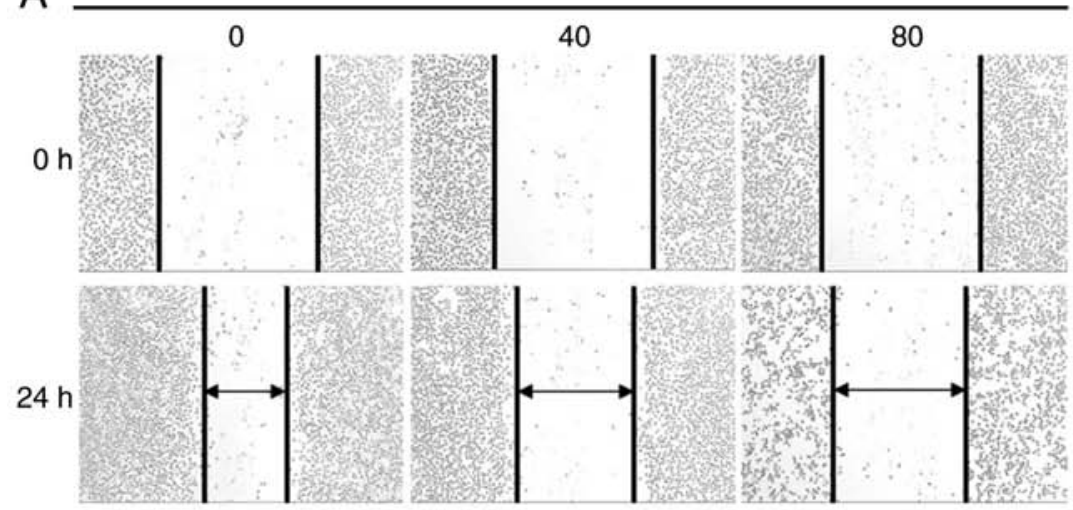

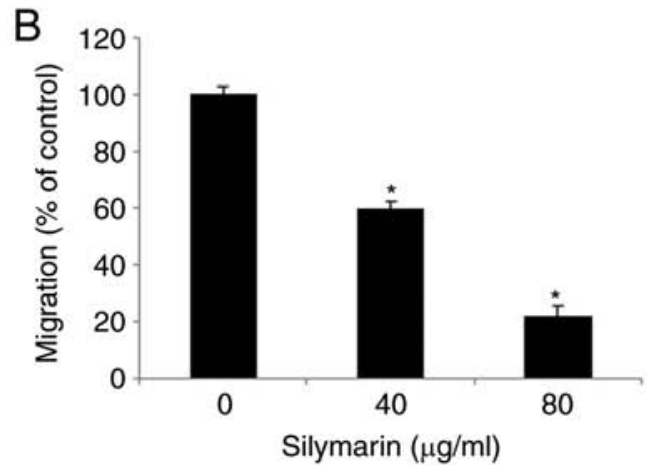

Figure 2. Effect of silymarin on the cell migration of AGS human gastric cancer cells. (A) AGS gastric cancer cells were treated with silymarin 0, 40 and $80 \mu \mathrm{g} / \mathrm{ml}$ for $24 \mathrm{~h}$, and cell migration was then measured by wound healing assays. (B) Width of the wound for any field of view was measured at 3-4 different locations. Data represent the means $\pm \mathrm{SD}$ of at least three replicates relative to the control (Dunnett's t-test with ${ }^{*} \mathrm{P}<0.05$ ).

A

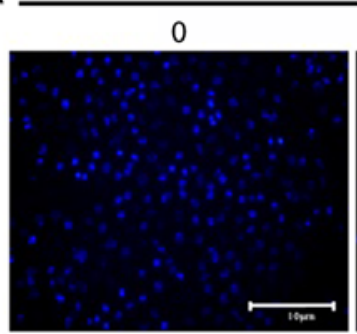

Silymarin $(\mu \mathrm{g} / \mathrm{ml})$

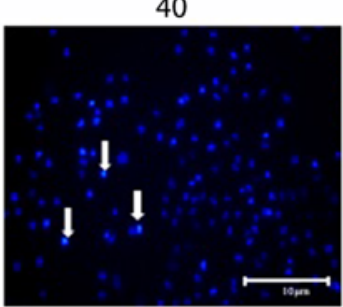

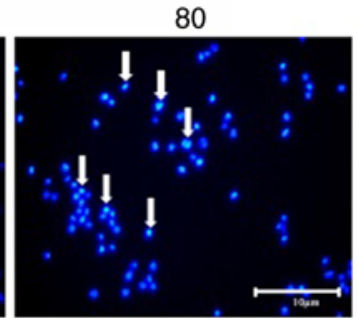

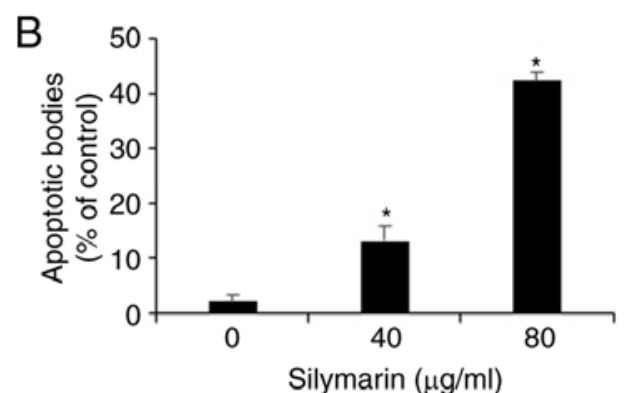

Figure 3. Effects of silymarin on apoptotic cell in AGS human gastric cancer cells. (A) AGS cells were treated with silymarin for $24 \mathrm{~h}$ and apoptotic bodies stained with DAPI. The arrows indicate chromatin condensation in the AGS cells. Fragmentation of nuclear DNA was examined by a fluorescence microscope (x200). Arrows indicate apoptotic bodies, which represent DNA fragments produced during apoptosis. (B) AGS cells were treated with silymarin for $24 \mathrm{~h}$ and nuclear condensation was examined by DAPI staining. Graphs reveal quantification of DNA fragmentation and nuclear condensation. Each bar represents the mean \pm SD calculated from five independent experiments. " $\mathrm{P}<0.05$, statistically significant compared with untreated controls (Dunnett's t-test).

A

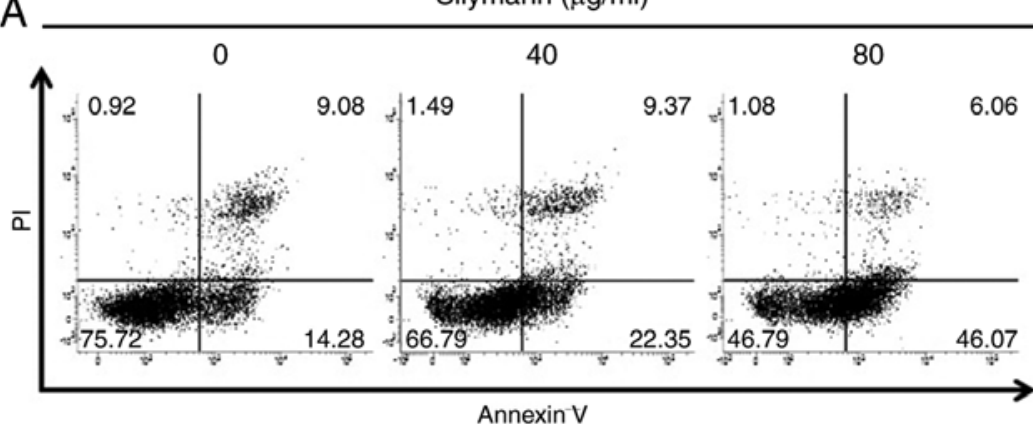

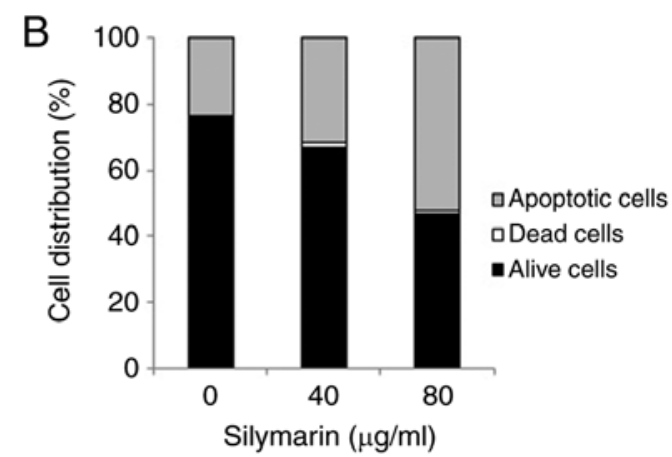

Figure 4. Effect of silymarin on apoptosis in AGS human gastric cancer cells. (A) The apoptotic effects of silymarin at different concentrations were evaluated by Annexin V-fluorescein and propidium iodide (PI) staining. AGS cells were treated with silymarin ( 0,40 , and $80 \mu \mathrm{g} / \mathrm{ml})$ for $24 \mathrm{~h}$ followed by flow cytometry. The lower left quadrant includes viable cells, which were negative for Annexin V-FITC binding (Annexin $\mathrm{V}^{-}$) and exclude PI (PI-); the lower right quadrant includes early apoptotic cells, which are positive for Annexin V-FITC binding (Annexin $\mathrm{V}^{+}$) but $\mathrm{PI}^{-}$; the upper right quadrant includes late apoptotic cells, which are Annexin $\mathrm{V}^{+}$and reveal PI uptake $\left(\mathrm{PI}^{+}\right)$; and the upper left quadrant includes necrotic cells, which are Annexin $\mathrm{V}^{-} / \mathrm{PI}^{+}$. (B) $\mathrm{Annexin} \mathrm{V} / \mathrm{PI}$ staining was revealed alive cell/dead cell/early-late apoptotic cell fluorescence intensity ratios.

group. At the end of the experimental period, the measured tumor weights were $1.14 \pm 0.17 \mathrm{~g}$ in the control group and $0.72 \pm 0.26 \mathrm{~g}$ in the $100 \mathrm{mg} / \mathrm{kg}$ silymarin group (Fig. 7B). The body weights of silymarin-treated and control mice remained similar throughout the experimental period (Fig. 7C).
Effects of silymarin on apoptosis induction of gastric tumor tissue. The tumors formed by subcutaneous transplantation of AGS human gastric cancer cells into 4-week-old male $\mathrm{BALB} / \mathrm{c}$ nude mice, as aforementioned, were extracted and examined by TUNEL assay to confirm the anticancer 

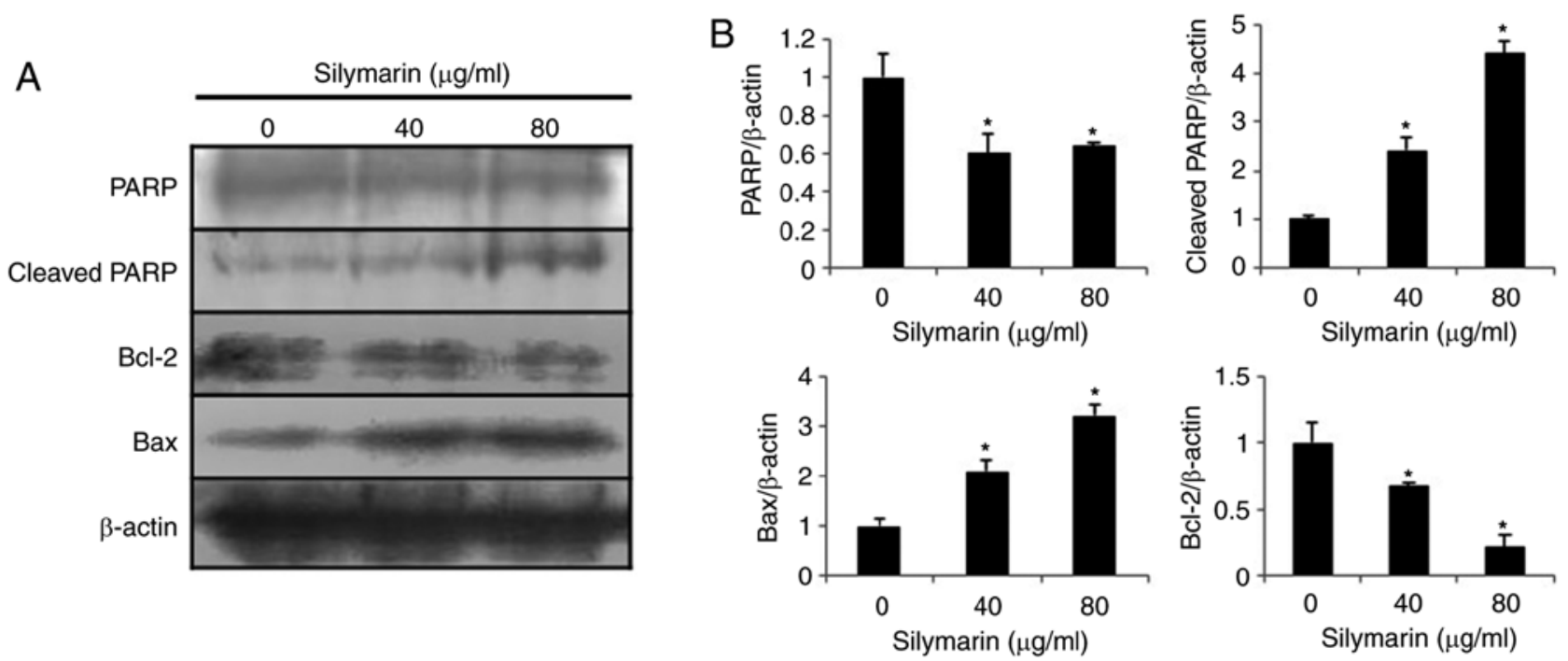

Figure 5. Effects of silymarin on apoptosis-related protein in AGS human gastric cancer cells. (A) AGS cells were treated with silymarin ( 0,40 and $80 \mu$ g/ml) for $24 \mathrm{~h}$ and cells were harvested to assess protein levels of Bax, Bcl-2, and PARP by western blotting. The blots were also probed with anti- $\beta$-actin antibody to confirm equal sample loading. (B) Each bar represents the mean \pm SD calculated from three independent experiments. * $\mathrm{P}<0.05$, statistically significant compared with untreated controls (Dunnett's t-test).
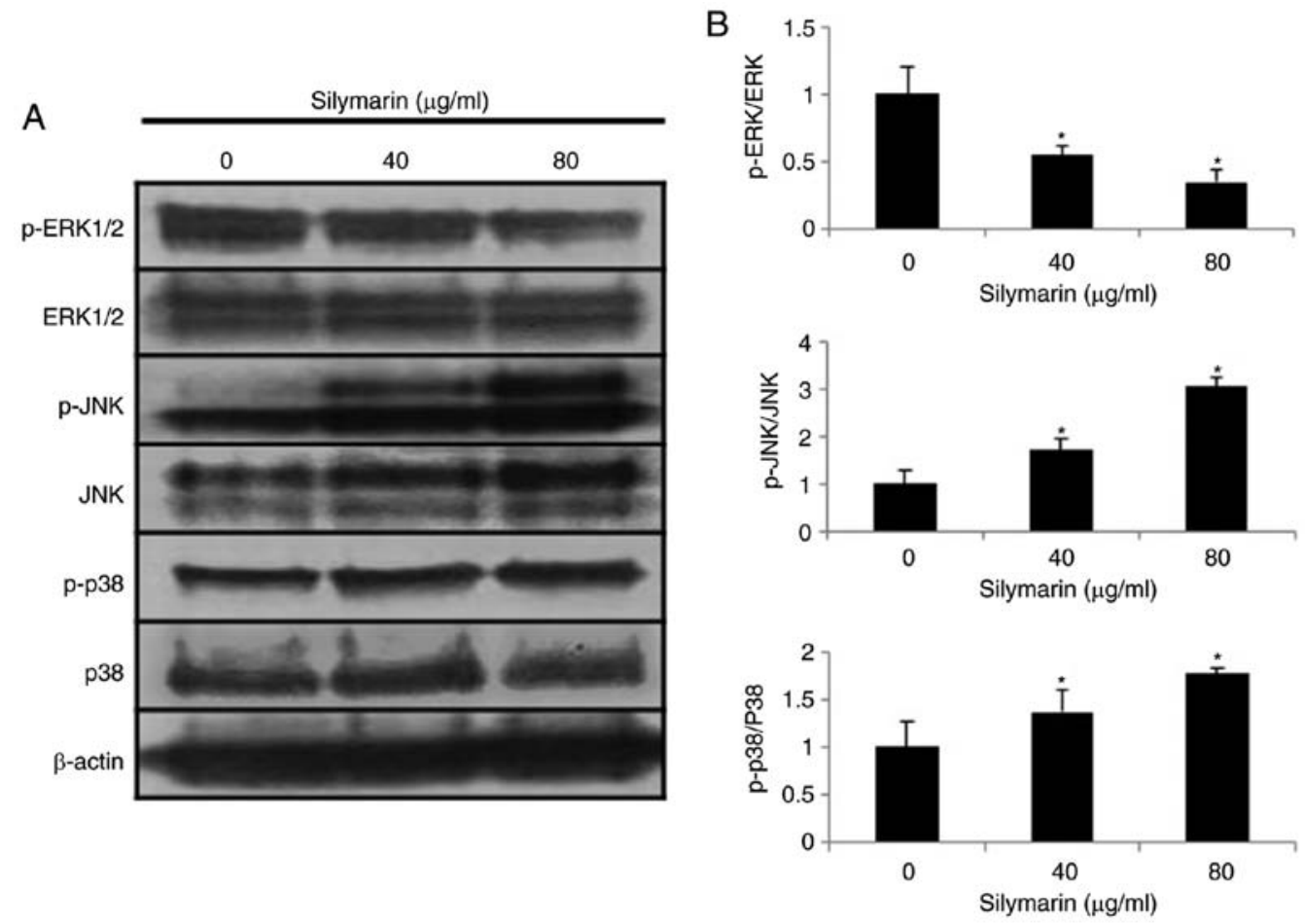

Figure 6. Effect of silymarin on the activation of MAPK pathway in AGS human gastric cancer cells. (A) AGS cells were treated with silymarin (0, 40 and $80 \mu \mathrm{g} / \mathrm{ml}$ ) for $24 \mathrm{~h}$. Cell lysates were prepared as described in Materials and methods, and analyzed by 12\% SDS-PAGE followed by western blotting. (B) Each bar represents the mean \pm SD calculated from independent experiments. ${ }^{*} \mathrm{P}<0.05$, statistically significant compared with the untreated controls (Dunnett's $\mathrm{t}$-test). MAPK, mitogen-activated protein kinase.

effect of silymarin in tumor tissue through the induction of apoptosis. AGS tumor tissue extracted from nude mice administered silymarin exhibited a significant increase in the proportion of TUNEL-positive cells compared to those without silymarin administration (Fig. 7D). The proportion of apoptotic cells revealed a significant increase of $26 \%$ in the $100 \mathrm{mg} / \mathrm{kg}$ silymarin group compared to the controls (Fig. 7E).
Effects of silymarin on the MAPK pathway in AGS gastric tumor tissue. Silymarin was administered to xenografted nude mice, and immunohistochemistry was performed to examine p-ERK1/2, p-JNK, and p-p38 expression (Fig. 8A). The group receiving $100 \mathrm{mg} / \mathrm{kg}$ silymarin exhibited a decrease in expression of p-ERK $1 / 2$ and increases in the expression of p-JNK and p-p38 in comparison with the control group. Quantitative comparison of the expression of each protein 
Table I. Tumor inhibition rate of mice implanted with AGS gastric cancer cells tumor-treated with silymarin.

\begin{tabular}{llll}
\hline Silymarin $(\mathrm{mg} / \mathrm{kg})$ & Pre-experiment size $\left(\mathrm{mm}^{3}\right)$ & Post-experiment size $\left(\mathrm{mm}^{3}\right)$ & Inhibition rate \\
\hline
\end{tabular}

\section{AGS}

$0^{\mathrm{a}}$

131.8

$1,230.7$

100

125.5

46.2

${ }^{\mathrm{a}}$ Control. ${ }^{\mathrm{b}} \mathrm{Data}$ are expressed as the percent relative to the control.

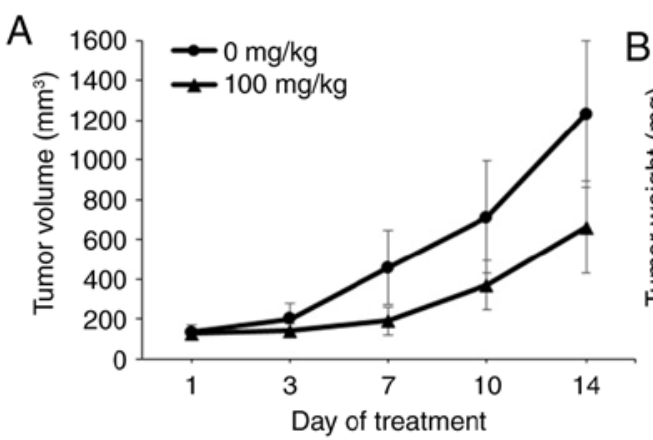

Silymarin $(\mathrm{mg} / \mathrm{kg})$

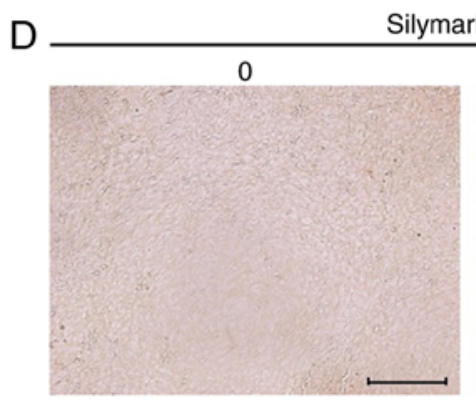

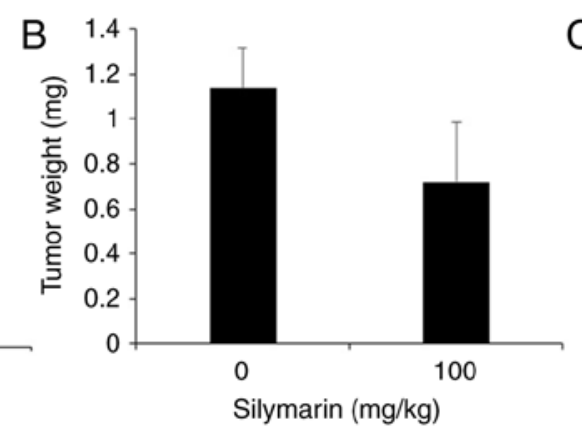
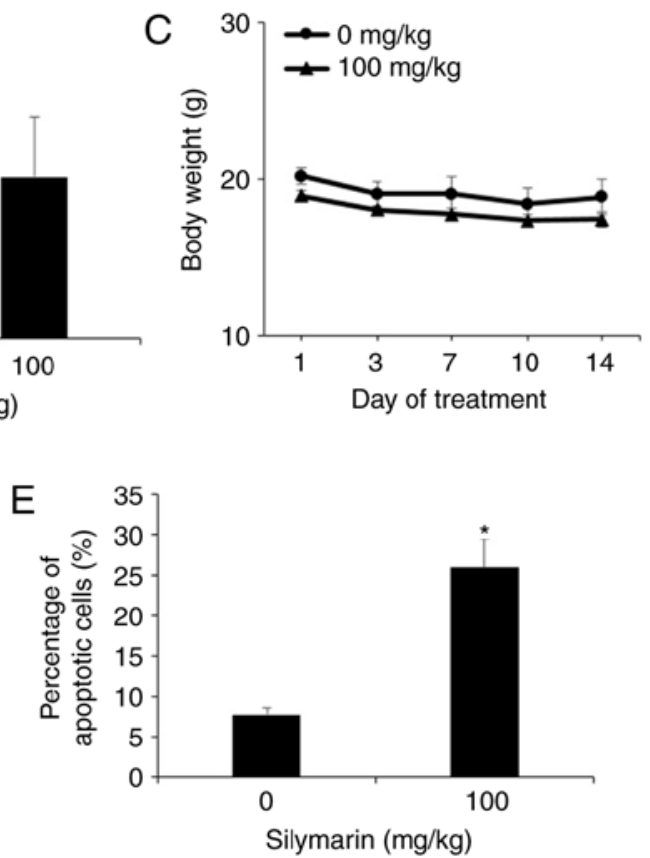

Figure 7. Effects of silymarin on AGS gastric cancer tumor xenograft growth and apoptosis in tumor tissues. Nude mice bearing AGS cells as xenograft models were treated with silymarin for 14 days, and (A) tumor volume, (B) tumor weight, and (C) body weight were determined. (D and E) Apoptosis was measured in tumor tissues by TUNEL assay. Slides were observed under an optical microscope (x200). Scale bar, $10 \mu \mathrm{m}$. * $\mathrm{P}<0.05$, each value represents the mean \pm standard error. Statistically significant compared with untreated controls (Dunnett's t-test).

resulted in a decrease of p-ERK1/2 from 34.4 to $8.6 \%$ in the silymarin-treated group, compared with the control group. Conversely, p-JNK increased from 6.2 to $31.4 \%$, and p-p38 from 9 to $23.6 \%$ (Fig. $8 \mathrm{~B}$ ).

Toxicity evaluation of silymarin in liver and kidney tissues. After the experimental period, the nude mice with transplanted AGS tumors were sacrificed to investigate for organ toxicity caused by administration of silymarin. The liver and kidneys were stained with H\&E and examined under an optical microscope (Fig. 9). The results indicated no histopathological abnormalities in the silymarin injection group or the non-injected control group.

\section{Discussion}

Infinite proliferation through acquisition of growth signaling and deviation of growth inhibition signals is one of the best-known features of cancer cells (33). To examine the viability and migration inhibitory effects in AGS human gastric cancer cells, an MTT assay was performed following silymarin treatment at concentrations of $0,20,40,60,80$, 100 and $120 \mu \mathrm{g} / \mathrm{ml}$ for $24 \mathrm{~h}$, and a wound healing assay was performed following silymarin treatment at 0,40 and $80 \mu \mathrm{g} / \mathrm{ml}$ for $24 \mathrm{~h}$. The results of the MTT assay revealed a concentration-dependent decrease in cell viability starting at $20 \mu \mathrm{g} / \mathrm{ml}$. In the wound healing assay, the groups treated with silymarin exhibited concentration-dependent inhibition of cell migration in comparison with the control group. Ramakrishnan et al (34) also demonstrated concentration-dependent inhibition of cancer cell viability beginning at a concentration of $50 \mu \mathrm{g} / \mathrm{ml}$ when liver cancer cells were treated with silymarin at concentrations of 50, 75, 100 and $200 \mu \mathrm{g} / \mathrm{ml}$ for $24 \mathrm{~h}$. Zhong et al (35) also treated leukemic cells with silymarin at 10,50 and $100 \mu \mathrm{g} / \mathrm{ml}$, and demonstrated a significant decrease in viability beginning at $50 \mu \mathrm{g} / \mathrm{ml}$. Fan et al (36) treated ovarian cancer cells with $25,50,100,150$ and $200 \mu \mathrm{g} / \mathrm{ml}$ silymarin and demonstrated a concentration-dependent decrease in viability from $50 \mu \mathrm{g} / \mathrm{ml}$. Significant decreases in viability were also observed with silymarin treatment at $100 \mu \mathrm{g} / \mathrm{ml}$ for 24,48 and $72 \mathrm{~h}$. Vaid et al (37) treated human melanoma cells with 
A
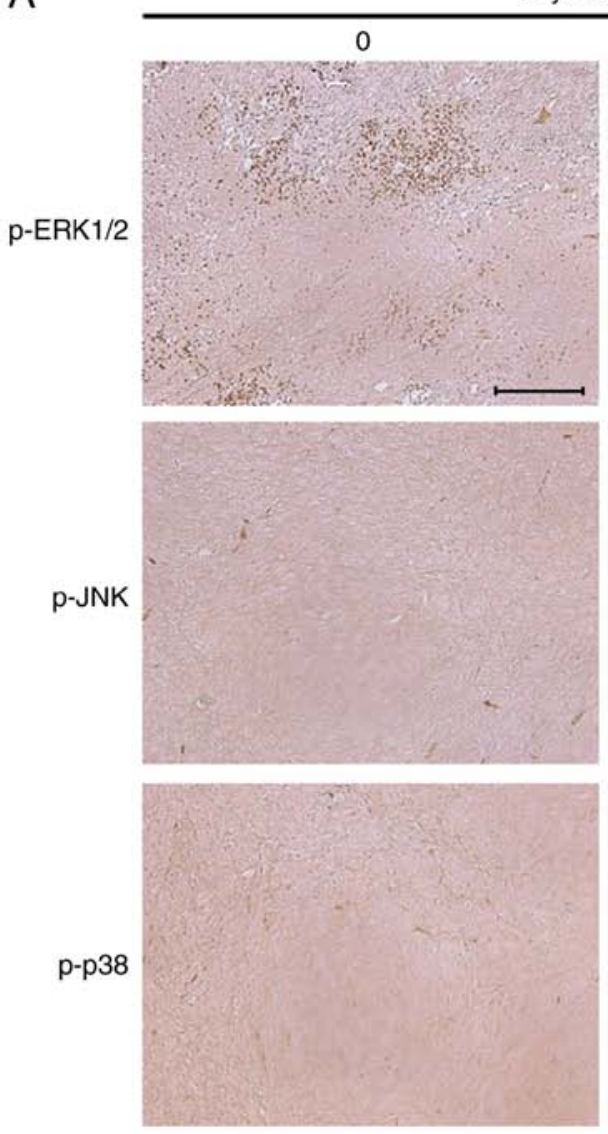

Silymarin $(\mathrm{mg} / \mathrm{kg})$

100
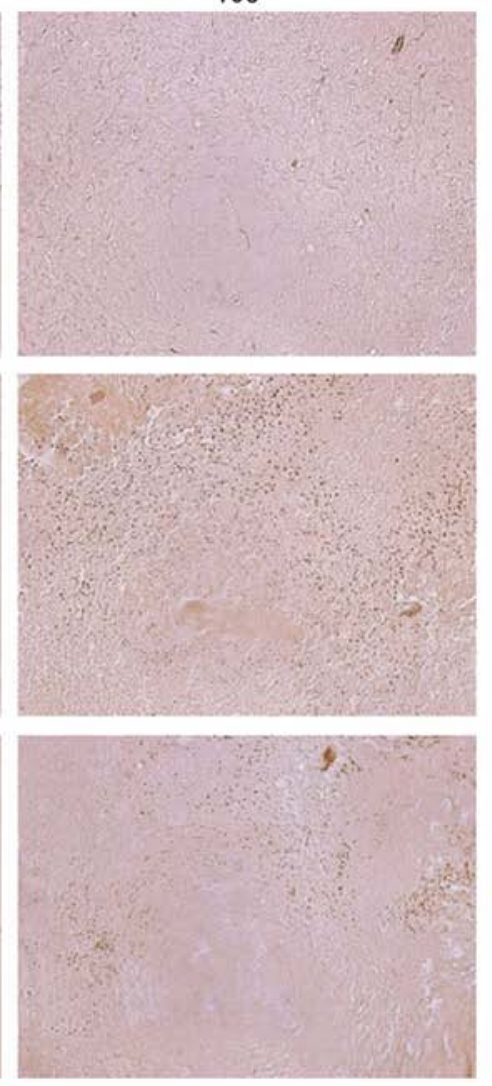
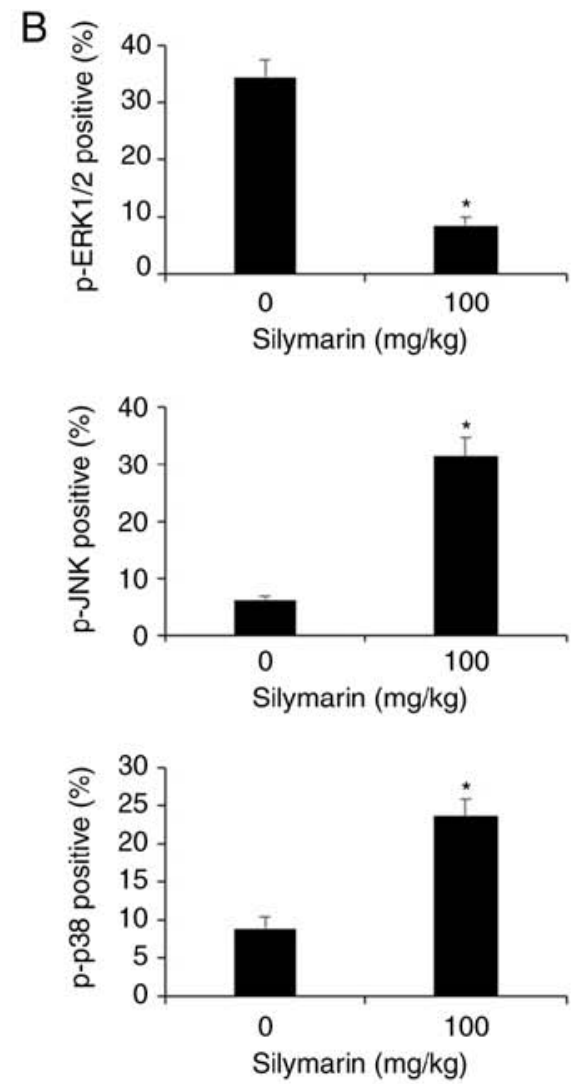

Figure 8. Effects of silymarin on MAPK expression in AGS gastric cancer tumor xenografts. (A) Nude mice were administered silymarin (0, 100 mg/kg) for 2 weeks and examined by immunohistochemistry using antibodies to p-ERK, p-JNK, and p-p38. Tumor tissues were observed under an optical microscope and images were captured at an x200 magnification. Paraffin-embedded tumor tissues were cut into sections 5- $\mu \mathrm{m}$ thick. Scale bar, $10 \mu \mathrm{m}$. (B) Graphs reveal quantification of each protein (p-ERK1/2, p-JNK and p-p38) with positive staining as determined by immunohistochemistry. Significance was determined by Dunnett's t-test with ${ }^{*} \mathrm{P}<0.05$ considered as statistically significant compared with non-treated controls. MAPK, mitogen-activated protein kinase.

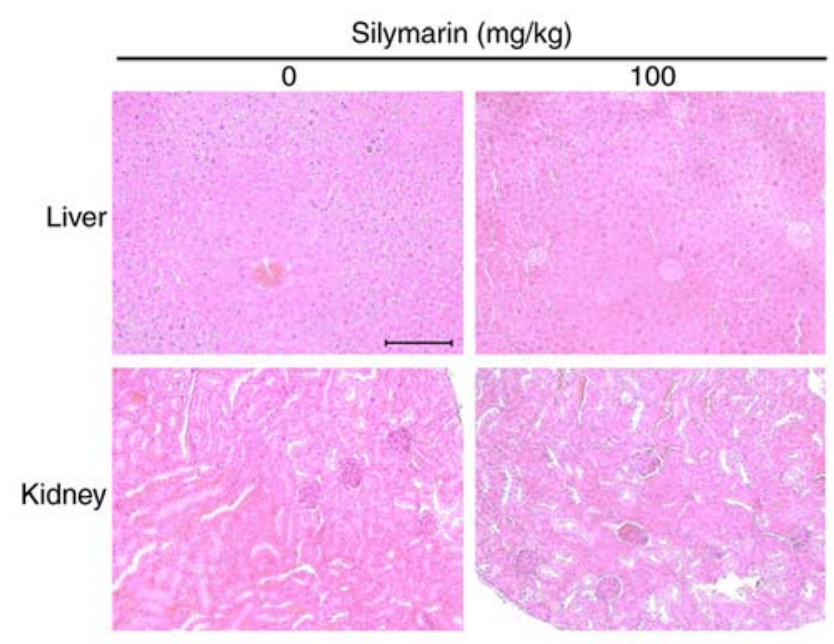

Figure 9. Histological analysis of silymarin-treated nude mice. The microscopic pathology of the liver and kidney revealed no evidence of adverse systemic toxicity of silymarin treatment in the mice. Slides were observed under an optical microscope (x200). Scale bar, $10 \mu \mathrm{m}$.

10,20 and $40 \mu \mathrm{g} / \mathrm{ml}$ silymarin and reported that the wound healing assay revealed significant inhibition of cell migration at concentrations of 20 and $40 \mu \mathrm{g} / \mathrm{ml}$. These findings indicated that silymarin decreased the viability and inhibited the migration of AGS human gastric cancer cells in this study.

When apoptosis occurs, apoptotic bodies are observed accompanied by cell and nuclear condensation and division, as well as dissolution of chromosomal DNA $(38,39)$. DAPI staining and flow cytometric analysis were conducted to confirm whether the viability decrease and inhibition of proliferation by silymarin in gastric cancer cells are caused by apoptosis. AGS cells were treated with silymarin at 0,40 and $80 \mu \mathrm{g} / \mathrm{ml}$ for $24 \mathrm{~h}$, and then subjected to staining with DAPI to identify apoptotic cells. DAPI-stained cells were counted to quantify the degree of apoptosis induction. The results indicated a dose-dependent increase in the number of DAPI-stained cells $(2 \%$ at $0 \mu \mathrm{g} / \mathrm{ml}, 13 \%$ at $40 \mu \mathrm{g} / \mathrm{ml}$ and $42.2 \%$ at $80 \mu \mathrm{g} / \mathrm{ml}$ ) in comparison with the control group. Fan et al (36) reported the occurrence of apoptosis in ovarian cancer cells following treatment with silymarin, while Katiyar et al (40) reported a concentration-dependent increase in apoptotic bodies with treatment of skin epidermal cancer cells with silymarin. The results of flow cytometric analysis confirmed the concentration-dependent increase in apoptotic cells by silymarin treatment $(23.26 \%$ at $0 \mu \mathrm{g} / \mathrm{ml}, 31.72 \%$ at $40 \mu \mathrm{g} / \mathrm{ml}$ and $52.13 \%$ at $80 \mu \mathrm{g} / \mathrm{ml}$ ). Zhong et al (35) also performed flow cytometric analysis of 
leukemic cells treated with silymarin at concentrations of 10,50 and $100 \mu \mathrm{g} / \mathrm{ml}$, and revealed a concentration-dependent increase in the proportion of apoptotic cells (3.24, $6.06,17.92$ and $67.83 \%$, respectively). Vaid et al (41) treated melanoma cells with silymarin at concentrations of 0,10 , $20,30,40$ and $60 \mu \mathrm{g} / \mathrm{ml}$ and performed flow cytometric analysis to confirm the concentration-dependent increase in the proportion of apoptotic cells. Therefore, the decreases in survival rate and cell proliferation of AGS human gastric cancer cells associated with silymarin treatment in the present study were determined to be due to the induction of apoptosis.

Apoptosis induction can be divided into the intrinsic pathway mediated by mitochondria and the extrinsic pathway mediated by death receptors $(27,28)$. The Bcl-2 family major proteins involved in the intrinsic pathway, among which Bax forms apoptosomes and activates caspase- 3 to induce apoptosis as a pro-apoptotic protein when its expression level is increased. On the other hand, Bcl-2 inhibits Bax as an anti-apoptotic protein to inhibit the induction of apoptosis (30). PARP, which plays an important role in the DNA repair, also regulates apoptosis (31). Therefore, western blotting analysis was performed to examine the changes in protein expression when apoptosis was induced by silymarin in AGS human gastric cancer cells. The results indicated concentration-dependent increases in expression levels of the pro-apoptosis proteins, cleaved PARP and Bax. By contrast, the expression level of the anti-apoptosis protein, $\mathrm{Bcl}-2$, was decreased by silymarin in a concentration-dependent manner. Katiyar et al (40) reported concentration-dependent increases in the expression of Bax and cleaved PARP and a concentration-dependent decrease in Bcl-2 expression in skin epidermal cancer cells following treatment with silymarin. Fan et al (36) also reported a concentration-dependent increase in Bax expression and decrease in Bcl-2 expression in silymarin-treated ovarian cancer cells. Ramakrishnan et al (34) reported a concentration-dependent increase in Bax expression following treatment of liver cancer cells with silymarin. These results indicated that silymarin altered the expression of apoptosis-related proteins to induce apoptosis in AGS human gastric cancer cells in a concentration-dependent manner.

As one of the protein kinase, mitogen-activated protein kinases (MAPK) is a major signaling pathway involved in delivering extracellular stimuli to the nucleus. MAPK can be divided into ERK1/2, which plays an important role in regulating cell proliferation, division, and viability, JNK/SAPK, and $\mathrm{p} 38$, which play essential roles in inflammation and cell death by reacting to various stimuli, such as extracellular stress (32). Therefore, silymarin-treated AGS human gastric cancer cells were subjected to western blotting to investigate the expression of ERK1/2, p38, and JNK, which are involved in MAPK signaling. Increases in the expression levels of p-p38 and p-JNK were observed, while p-ERK1/2 expression decreased in a concentration-dependent manner in AGS cells treated with silymarin at 0,40 and $80 \mu \mathrm{g} / \mathrm{ml}$ for $24 \mathrm{~h}$. Yan et al (42) observed a concentration-dependent decrease in p-ERK1/2 expression in A431 human epidermal cancer cells treated with silymarin. Huang et al (43) reported the concentration-dependent regulation of p-p38 and p-JNK expression in silymarin-treated HeLa ovarian cancer cells. In summary, silymarin appears to inhibit the growth and proliferation of cells by regulating MAPK signaling and inducing apoptosis in vitro.

AGS cells were injected into nude mice, and silymarin was orally administered for 2 weeks at concentrations of 0 and $100 \mathrm{mg} / \mathrm{kg}$ to examine its effects on the tumor xenograft. The tumor size began to vary in the silymarin injection group on day 7 after commencement of administration. On day 14 , the tumor size was inhibited by $46.2 \%$ in the silymarin injection group in comparison with the control group. The tumor weights were $1.14 \mathrm{~g}$ in the control group and $0.72 \mathrm{~g}$ in the injection group, indicating the inhibition of tumor growth in the silymarin injection group. Won et al (44) orally administered silymarin at the concentration of $200 \mathrm{mg} / \mathrm{kg}$ to animals with HSC-4 oral cancer tumor xenografts five times a week for 5 weeks, and reported the inhibition of tumor growth in the silymarin injection group in comparison with the control. These findings suggest that silymarin also inhibited the growth of AGS human gastric cancer cells.

To examine whether the inhibition of tumor growth was mediated by apoptosis, the extracted tumors were subjected to TUNEL assay. The results indicated a $26 \%$ increase in TUNEL-positive apoptotic cells in the $100 \mathrm{mg} / \mathrm{kg}$ silymarin injection group compared to the control group. Singh et al (45) also reported an increase in TUNEL-positive apoptotic cells in skin cancer tumors extracted from mice treated with silymarin. Therefore, silymarin was suggested to inhibit tumor growth by inducing apoptosis in the AGS tumor xenografts in the present study.

ERK1/2 plays an important role in cell proliferation and division, while JNK and p38 are major factors involved in the MAPK signaling pathway, which is essential for cell death in response to extracellular stimuli (32). Therefore, immunohistochemical analyses were performed to examine the expression of proteins involved in the MAPK signaling pathway in extracted tumor tissue in relation to silymarin treatment. The results indicated decreased expression of p-ERK1/2 and increased p-JNK and p-p38 expression in the silymarin injection group $(100 \mathrm{mg} / \mathrm{kg})$ compared with the control group. These observations were consistent with the effects of silymarin on regulation of MAPK signaling pathway-related factors, $\mathrm{p}$-ERK1/2, $\mathrm{p}-\mathrm{JNK}$, and p-p38 in vitro as determined by western blotting analyses.

Therefore, the present study indicated that silymarin is highly promising for the development of gastric cancer medications as it inhibits cell growth and tumor generation by inducing apoptosis in AGS human gastric cancer cells both in vitro and in vivo.

\section{Acknowledgements}

Not applicable.

\section{Funding}

The present research was supported by the Basic Science Research Program through the National Research Foundation of Korea (NRF) funded by the Ministry of Education, Science and Technology (NRF 2017R1A2B4005516). 


\section{Availability of data and materials}

The datasets used during the present study are available from the corresponding author upon reasonable request.

\section{Authors' contributions}

SHK performed the experiments, analyzed the data and wrote the manuscript. GSC, ESY, JSW, SHH and JHL helped perform the experiments and assembled the data. SHK and JSW performed the statistical analysis. SHK and ESY analyzed and interpreted the results. JYJ designed the experiments and contributed to the drafting of manuscript as a supervisor. All authors read and approved the final manuscript and agree to be accountable for all aspects of the research in ensuring that the accuracy or integrity of any part of the work are appropriately investigated and resolved.

\section{Ethics approval and consent to participate}

The animal experiments were conducted in accordance with the regulations of the Institutional Animal Care and Use Committee with the approval of the Ethics Committee of Kongju National University.

\section{Patient consent for publication}

Not applicable.

\section{Competing interests}

The authors declare that they have no competing interests.

\section{References}

1. Jung KW, Won YJ, Kong HJ and Lee ES: Prediction of cancer incidence and mortality in Korea, 2019. Cancer Res Treat 51 431-437, 2019.

2. Won YJ, Sung J, Jung KW, Kong HJ, Park S, Shin HR, Park EC, Ahn YO, Hwang IK, Lee DH, et al: Nationwide cancer incidence in Korea, 2003-2005. Cancer Res Treat 41: 122-131, 2009

3. Jung KW, Won YJ, Kong HJ, Oh CM, Lee DH and Lee JS: Cancer statistics in Korea: Incidence, mortality, survival, and prevalence in 2011. Cancer Res Treat 46: 109-123, 2014.

4. Jemal A, Center MM, DeSantis C and Ward EM: Global patterns of cancer incidence and mortality rates and trends. Cancer Epidemiol Biomarkers Prev 19: 1893-1907, 2010.

5. Ferlay J, Shin HR, Bray F, Forman D, Mathers C and Parkin DM: Estimates of worldwide burden of cancer in 2008: GLOBOCAN 2008. Int J Cancer 127: 2893-2917, 2010.

6. Forman D and Burley VJ: Gastric cancer: Global pattern of the disease and an overview of environmental risk factors. Best Pract Res Clin Gastroenterol 20: 633-649, 2006.

7. Lee MS, Cha EY, Thuong PT, Kim JY, Ahn MS and Sul JY: Down-regulation of human epidermal growth factor receptor $2 /$ neu oncogene by corosolic acid induces cell cycle arrest and apoptosis in NCI-N87 human gastric cancer cells. Biol Pharm Bull 33: 931-937, 2010.

8. Li N, Fan LL, Sun GP, Wan XA, Wang ZG, Wu Q and Wang H: Paeonol inhibits tumor growth in gastric cancer in vitro and in vivo. World J Gastroenterol 16: 4483-4490, 2010.

9. Zhang L, Hou YH, Wu K, Zhai JS and Lin N: Proteomic analysis reveals molecular biological details in varioliform gastritis without helicobacter pylori infection. World J Gastroenterol 16: 3664-3673, 2010.

10. Seeram NP: Berry fruits for cancer prevention: Current status and future prospects. J Agric Food Chem 56: 630-635, 2008
11. An IJ, Kwon JK, Lee JS, Park HS, Kim DC, Choi BJ, Lee KM, Park YJ and Jung JY: Induction of apoptosis in human cancer cells with compositae extracts. J Korean Soc Food Sci Nutr 41: 584-590, 2012.

12. Kwon MJ and Nam TJ: A polysaccharide of the marine alga capsosiphon fulvescens induces apoptosis in AGS gastric cancer cells via an IGF-IR-mediated PI3K/Akt pathway. Cell Biol Int 31: 768-775, 2007.

13. Schuier M, Sies H, Illek B and Fischer H: Cocoa-related flavonoids inhibit CFTR-mediated chloride transport across T84 human colon epithelia. J Nutr 135: 2320-2325, 2005.

14. Murakami A, Ashida $\mathrm{H}$ and Terao J: Multitargeted cancer prevention by quercetin. Cancer Lett 269: 315-325, 2008.

15. Ren W, Qiao Z, Wang H, Zhu L and Zhang L: Flavonoids: Promising anticancer agents. Med Res Rev 23: 519-534, 2003.

16. Hackett ES, Twedt DC and Gustafson DL: Milk thistle and its derivative compounds: A review of opportunities for treatment of liver disease. J Vet Intern Med 27: 10-16, 2013.

17. Chen $\mathrm{CH}$, Huang TS, Wong $\mathrm{CH}$, Hong $\mathrm{CL}$, Tsai $\mathrm{YH}$, Liang $\mathrm{CC}$, Lu FJ and Chang WH: Synergistic anti-cancer effect of baicalein and silymarin on human hepatoma HepG2 Cells. Food Chem Toxicol 47: 638-644, 2009.

18. Ramasamy K and Agarwal R: Multitargeted therapy of cancer by silymarin. Cancer Lett 269: 352-362, 2008.

19. Surai PF: Silymarin as a natural antioxidant: An overview of the current evidence and perspectives. Antioxidants (Basel) 4: 204-247, 2015.

20. Katiyar SK: Silymarin and skin cancer prevention: Anti-inflammatory, antioxidant and immunomodulatory effects (Review). Int J Oncol 26: 169-176, 2005.

21. Féher J and Lengyel G: Silymarin in the prevention and treatment of liver diseases and primary liver cancer. Curr Pharm Biotechnol 13: 210-217, 2012.

22. Eo HJ, Park GH and Jeong JB: Inhibition of Wnt signaling by silymarin in human colorectal cancer cells. Biomol Ther (Seoul) 24: 380-386, 2016.

23. Hajighasemlou S, Farajollahi M, Alebouyeh M, Rastegar H, Manazi MT, Mirmoghtadaei M, Moayedi B, Ahmadzadeh M, Kazemi M, Parvizpour F and Gharibzadeh S: Study of the effect of silymarin on viability of breast cancer cell lines. Adv Breast Cancer Res 3: 100-105, 2014.

24. Wu T, Liu W, Guo W and Zhu X: Silymarin suppressed lung cancer growth in mice via inhibiting myeloid-derived suppressor cells. Biomed Pharmacother 81: 460-467, 2016.

25. Deep G, Singh RP, Agarwal C, Kroll DJ and Agarwal R: Silymarin and silibinin cause G1 and G2-M cell cycle arrest via distinct circuitries in human prostate cancer PC3 cells: A comparison of flavanone silibinin with flavanolignan mixture silymarin. Oncogene 25: 1053-1069, 2006.

26. Hsu HF, Houng JY, Kuo CF, Tsao N and Wu YC: Glossogin, a novel phenylpropanoid from glossogyne tenuifolia, induced apoptosis in A549 lung cancer cells. Food Chem Toxicol 46: 3785-3791, 2008.

27. Kaufmann T, Strasser A and Jost PJ: Fas death receptor signalling: Roles of Bid and XIAP. Cell Death Differ 19: 42-50, 2012.

28. Tummers B and Green DR: Caspase-8: Regulating life and death. Immunol Rev 277: 76-89, 2017.

29. Kim D and Chung J: Akt: Versatile mediator of cell survival and beyond. J Biochem Mol Biol 35: 106-115, 2002.

30. Burz C, Berindan-Neagoe I, Balacescu O and Irimie A: Apoptosis in cancer: Key molecular signaling pathways and therapy targets. Acta Oncol 48: 811-821, 2009.

31. Soldani C and Scovassi AI: Poly (ADP-ribose) polymerase-1 cleavage during apoptosis: An update. Apoptosis 7: 321-328, 2002.

32. Kim EK and Choi EJ: Pathological roles of MAPK signaling pathways in human diseases. Biochim Biophys Acta 1802: 396-405, 2010.

33. Hanahan D and Weinberg RA: Hallmarks of cancer: The next generation. Cell 144: 646-674, 2011.

34. Ramakrishnan G, Lo Muzio L, Elinos-Báez CM, Jagan S, Augustine TA, Kamaraj S, Anandakumar P and Devaki T: Silymarin inhibited proliferation and induced apoptosis in hepatic cancer cells. Cell Prolif 42: 229-240, 2009.

35. Zhong X, Zhu Y, Lu Q, Zhang J, Ge Z and Zheng S: Silymarin causes caspases activation and apoptosis in K562 leukemia cells through inactivation of Akt pathway. Toxicology 227: 211-216, 2006.

36. Fan L, Ma Y, Liu Y, Zheng D and Huang G: Silymarin induces cell cycle arrest and apoptosis in ovarian cancer cells. Eur J Pharmacol 743: 79-88, 2014. 
37. Vaid M, Prasad R, Sun Q and Katiyar SK: Silymarin targets $\beta$-catenin signaling in blocking migration/invasion of human melanoma cells. PLoS One 6: e23000, 2011.

38. Danial NN and Korsmeyer SJ: Cell death: Critical control points. Cell 116: 205-219, 2004.

39. Halicka HD, Bedner E and Darzynkiewicz Z: Segregation of RNA and separate packaging of DNA and RNA in apoptotic bodies during apoptosis. Exp Cell Res 260: 248-256, 2000.

40. Katiyar SK, Roy AM and Baliga MS: Silymarin induces apoptosis primarily through a p53-dependent pathway involving Bcl-2/Bax, cytochrome c release, and caspase activation. Mol Cancer Ther 4: 207-216, 2005.

41. Vaid M, Singh T, Prasad R and Katiyar SK: Silymarin inhibits melanoma cell growth both in vitro and in vivo by targeting cell cycle regulators, angiogenic biomarkers and induction of apoptosis. Mol Carcinog 54: 1328-1339, 2015.

42. Yan C, Yahua WU, Wang Z, Yin C and Yin M: Inhibitory effect of silymarin on human osteosarcoma Saos-2 cells and its mechanism. Chin Pharmacol Bull 32: 966-969, 2016 (In Chinese).
43. Huang Q, Wu LJ, Tashiro S, Onodera S, Li LH and Ikejima T: Silymarin augments human cervical cancer HeLa cell apoptosis via P38/JNK MAPK pathways in serum-free medium. J Asian Nat Prod Res 7: 701-709, 2005.

44. Won DH, Kim LH, Jang B, Yang IH, Kwon HJ, Jin B, Oh SH, Kang JH, Hong SD, Shin JA and Cho SD: In vitro and in vivo anti-cancer activity of silymarin on oral cancer. Tumor Biol 40: 1010428318776170, 2018.

45. Singh RP, Tyagi AK, Zhao J and Agarwal R: Silymarin inhibits growth and causes regression of established skin tumors in SENCAR mice via modulation of mitogen-activated protein kinases and induction of apoptosis. Carcinogenesis 23: 499-510, 2002.

This work is licensed under a Creative Commons Attribution-NonCommercial-NoDerivatives 4.0 International (CC BY-NC-ND 4.0) License. 